\title{
Fungal parasites of marine algae from Mandapam (South India)
}

\section{Chandralata Raghukumar}

Biological Oceanography Division, National Institute of Oceanography, Dona Paula, Goa 403004 , India

\begin{abstract}
Several fungal parasites of marine algae from Mandapam, on the east coast of south India, are reported. The green alga Chaetomorpha media (C. Agardh) Kützing collected from intertidal rocks showed the presence of the fungal parasites Pontisma lagenidioides Petersen and Labyrinthula sp. on incubation in sterile seawater under laboratory conditions. Whole plants were destroyed within 12 to $15 \mathrm{~d}$. Similarly, the blue-green alga Lyngbya sp. and the green filamentous algae Rhizoclonium sp. and Cladophora sp., incubated in seawater, showed severe infection by Labyrinthula sp. The host range of Labyrinthula sp. and culturing methods are also discussed. These pathogens are new records from India and some of the host/parasite combinations reported here are also new. Species of Cladophora showed infection by Sirolpidium bryopsidis (de Bruyne) H. E. Petersen and Olpidium rostriferum Tokunaga. An epiphytic chytrid on the brown alga Sphacelaria sp. was identified as Chytridium polysiphoniae Cohn
\end{abstract}

\section{INTRODUCTION}

This work was initiated in a search for virulent marine fungal pathogens or potential pathogens for use in biological control of nuisance algae. Biological control of fouling algae has received little consideration, although there are reports of anti-algal activity of fungi (Redhead \& Wright 1978, Bott \& Rogenmuser 1980).

Several marine fungi have already been reported as pathogens of marine algae (Andrews 1976, Porter 1986). C. Raghukumar (1986a, b, c) has also reported several fungal parasites of green algae and diatoms from India. Several fungal pathogens of algae from the southeastern coast of India are reported here. Laboratory findings on Chaetomorpha media and its pathogens from Goan beaches are reported in the companion article (Raghukumar 1987).

\section{MATERIALS AND METHODS}

Algal specimens were collected from intertidal regions during low tides, in the vicinity of Tuticorin and Mandapam on the southeastern coast of India (Fig. 1). They were thoroughly cleaned and incubated in sterile seawater. Specimens were washed for $30 \mathrm{~s}$ in a $0.1 \%$ solution of streptomycin and penicillin and rinsed in sterile seawater. They were transported on ice to avoid overheating. Sterile seawater, without added nutrients, was replaced daily for the first week after collection and thereafter, every $5 \mathrm{~d}$. Most of the algae incubated in this way remained without excess bacterial growth and healthy. The algae were inspected daily for about 2 wk under a stereo-microscope and light microscope for fungal pathogens.

Algae used for isolating Labyrinthula sp. were washed 5 times with sterile seawater and plated on Thraustochytrid medium (S. Raghukumar 1986) with $0.001 \%$ cholesterol. The culture of Labyrinthula sp. was maintained on autoclaved filaments of Chaetomorpha media in sterile seawater.

\section{RESULTS}

During the incubation in sterile seawater, some of the algae started showing the presence of fungal species belonging to the Mastigomycotina even after $3 \mathrm{~d}$. Some of these fungi turned out to be pathogens of these algae under laboratory conditions. These diseases are described below.

\section{Browning disease of Chaetomorpha media}

Infected filaments of Chaetomorpha media (C. Agardh) Kützing showed a gradual browning from the 


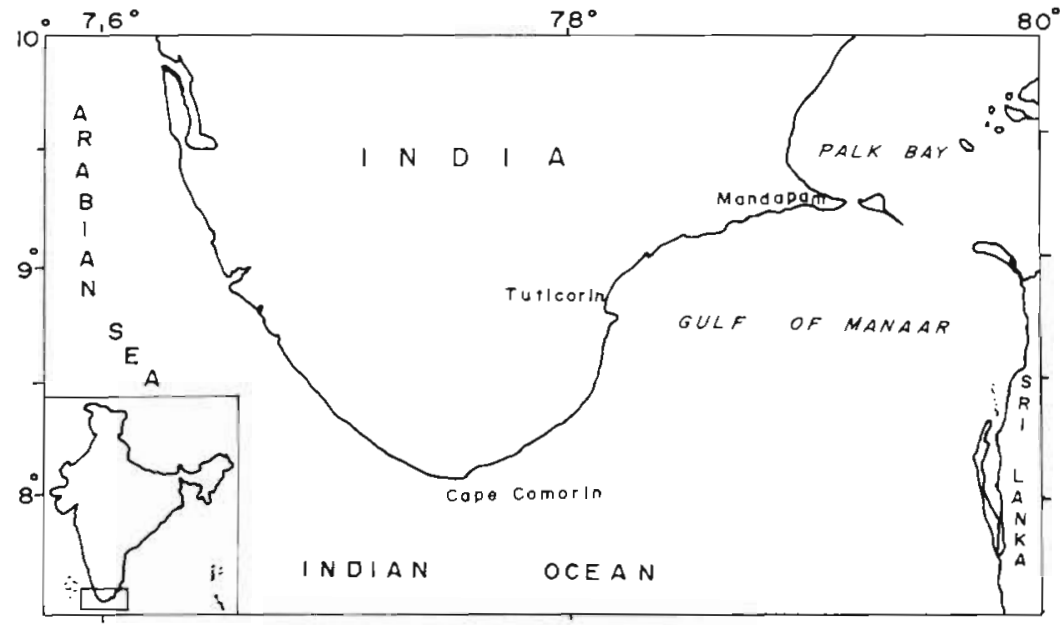

tip downward on incubation in seawater. This browning was distinctly visible after the third day (Fig. 2). Filaments turned almost completely brown by the twelfth or fifteenth day (Fig. 3). This browning was associated with infection as it was observed under the microscope that cells containing fungal sporangia were brown, in contrast to healthy cells which remained green. Freshly collected plants of $C$. media were very rigid, but as the infection progressed, the plants lost their turgidity and became limp.

The young fungal thallus at early stages of infection appeared knob-like inside the cell (Fig. 4 \& 5). The thallus further developed into a tubular filament (15 to $20 \mu \mathrm{m}$; Fig. $6 \&$ 7), became septate (Fig. $7 \&$ 14) and then fragmented into a number of segments (Fig. 8 to 11). These segments ( 30 to $60 \mu \mathrm{m}$ in length) developed into sporangia (Fig. 11 to 14). Some of the sporangia were olpidioid in shape (14 to $20 \mu \mathrm{m})$, some elongated (Fig. 14; 30 to $60 \mu \mathrm{m}$ in length) and some were even lobed (Fig, 11). These sporangia developed simple or branched discharge tubes (Fig. 15 \& 16) varying from 40 to $100 \mu \mathrm{m}$ in length. The discharge tubes remained intramatrical (within the algal cell) or sometimes penetrated the host cell wall and projected out for a great distance (100 to $120 \mu \mathrm{m}$ )

The contents of the fungal thalli appeared glistening and refringent with numerous globules (Fig. 11, 12 \& 14). The contents cleaved into zoospores which showed a gentle rocking movement inside zoosporangium. Later on, this movement became vigorous, zoospores came out singly from the tip of the discharge tube, and swam away directly (Fig. 15 \& 16) or encysted inside the host cell (Fig. 17). The zoospores possessed 2 oppositely directed flagella.

From the above characteristics and developmental stages observed, this fungus was identified as Pontisma lagenidioides Petersen (Sparrow 1960).
Fig. 1. Map showing collection sites

\section{Disease symptoms}

The chloroplasts in a healthy cell of Chaetomorpha media are tightly packed (Fig. 4). As the infection set in and the fungal thallus developed into filaments which further fragmented into segments, the chloroplasts in the host cell aggregated along the sporangial wall (Fig. 12 to 14). They were initially green in colour and turned brown as the infection continued (Fig. $11 \& 14$ ). Later the brown pigmented bodies disappeared completely when only empty sporangia with their persistent discharge tubes filled the infected cells.

\section{Labyrinthula infection of Chaetomorpha media}

Chaetomorpha media collected from Mandapam on incubation in seawater was found to be infected with Labyrinthula sp. (Fig. 18). To the naked eye, the infected plants appeared pale green. Under the microscope, the cells were observed to be filled with a labyrinth of spindle-shaped cells in an ectoplasmic network (Fig. $19 \& 20$ ). As the organism multiplied inside the host cell, the chloroplasts aggregated into a sphere (Fig. 31) in the centre of the host cell (Fig. 20). Browning of cell content was not observed here. In some places, the cells of Labyrinthula formed large golden-brown sori (Fig. 31).

In some instances cells of Labyrinthula $\mathrm{sp}$. were found growing in algal cells which were already infected with Pontisma lagenidioides (Fig 21 \& 22). The network of cells of Labyrinthula was seen growing on and around the fungal sporangia of $P$. lagenidioides.

Labyrinthula sp. was cultured on autoclaved filaments of Chaetomorpha media (Fig. 23 to 25). Here it produced large golden brown sori (Fig. 24). It could be 
Fig. 2 \& 3. Chaetomorpha media. Fig. 2. Filaments showing healthy (arrow) and infected (arrow-head) cells $(\times 5)$. Infected cells have a granulated appearance whereas the healthy cells have a smooth, shiny and turgid appearance. Fig. 3. Healthy $(\mathrm{H})$ and infected (I) plants. Infected plants appeared completely brown $(\times 1.2)$
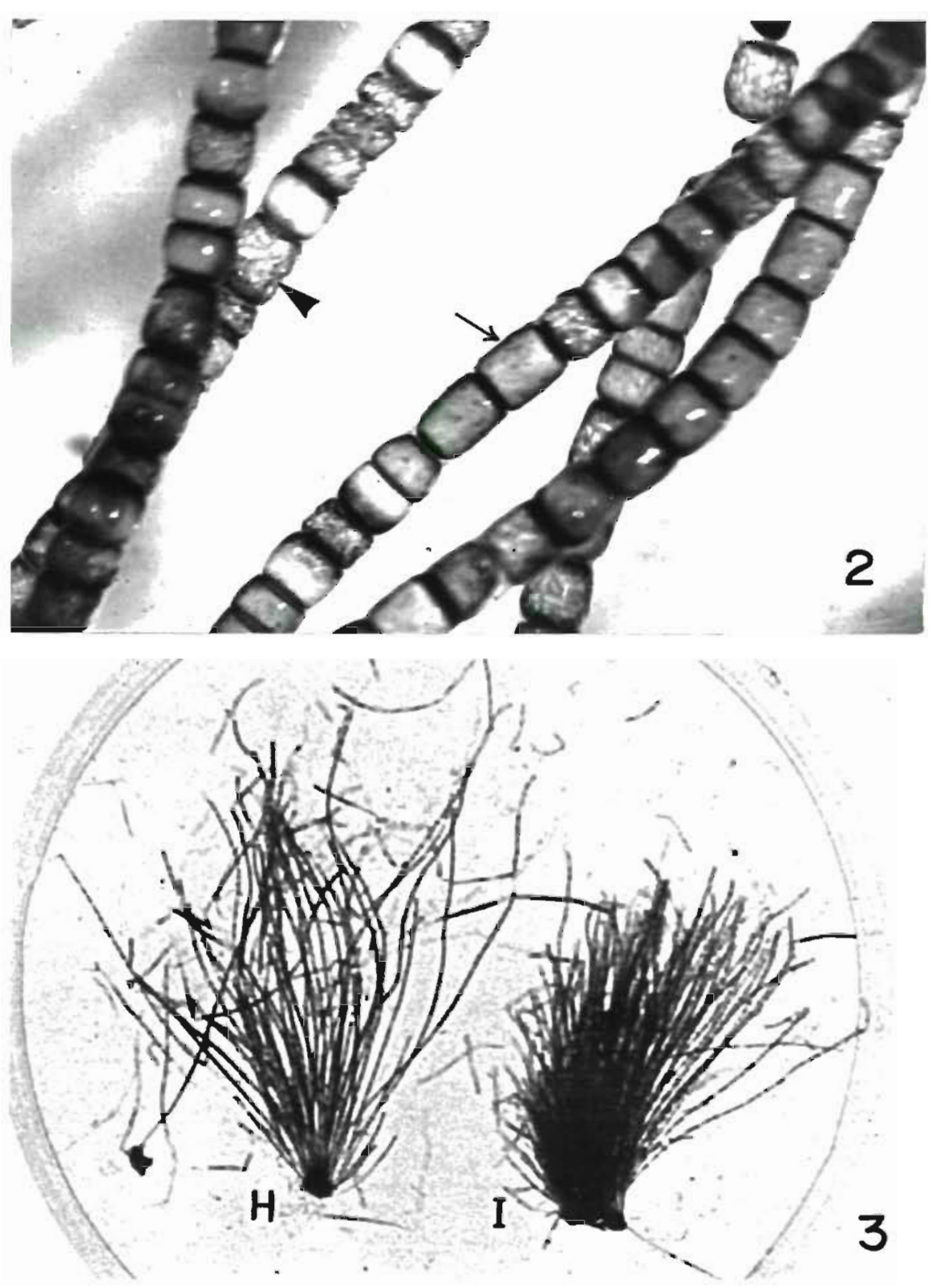

isolated from the infected plant in seawater enriched with $0,001 \%$ cholesterol and baited with pine pollen (Fig. 26).

\section{Infection of other algae by Labyrinthula sp.}

The blue-green alga Lyngbya sp. collected from Mandapam was found to be heavily infected with Labyrinthula sp. as observed after $6 \mathrm{~d}$ incubation in sterile seawater. It was observed growing in live filaments (Fig. 27 to 30) where the adjacent chromatoplasm was still green. The spindle-shaped Labyrin- thula cells were seen growing between the cell wall and the chromatoplasm (Fig. 27 to 29). In some instances where Labyrinthula was found growing luxuriantly, the host was devoid of its content (Fig. 30).

Labyrinthula sp. was also seen growing profusely in Cladophora sp. and Rhizoclonium sp. Chloroplasts of the infected host cells were found to be displaced. Labyrinthula sp. was also isolated from the red alga Laurencia sp. and the brown alga Lobophora variegata by plating them on Thraustochytrid medium (S. Raghukumar 1986) enriched with $0.001 \%$ cholesterol. These plants did not show any external symptoms of disease (Fig. 36). 

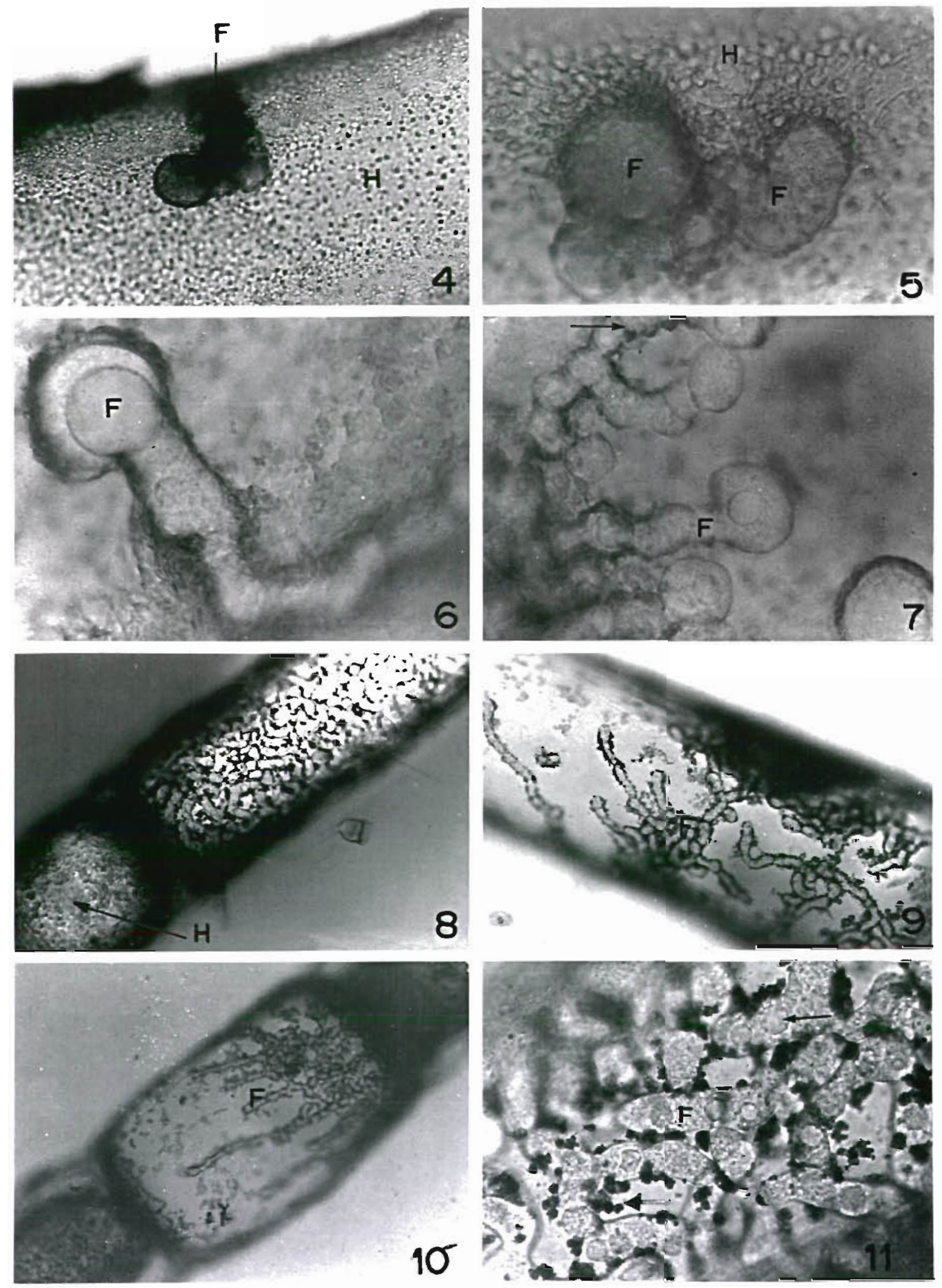

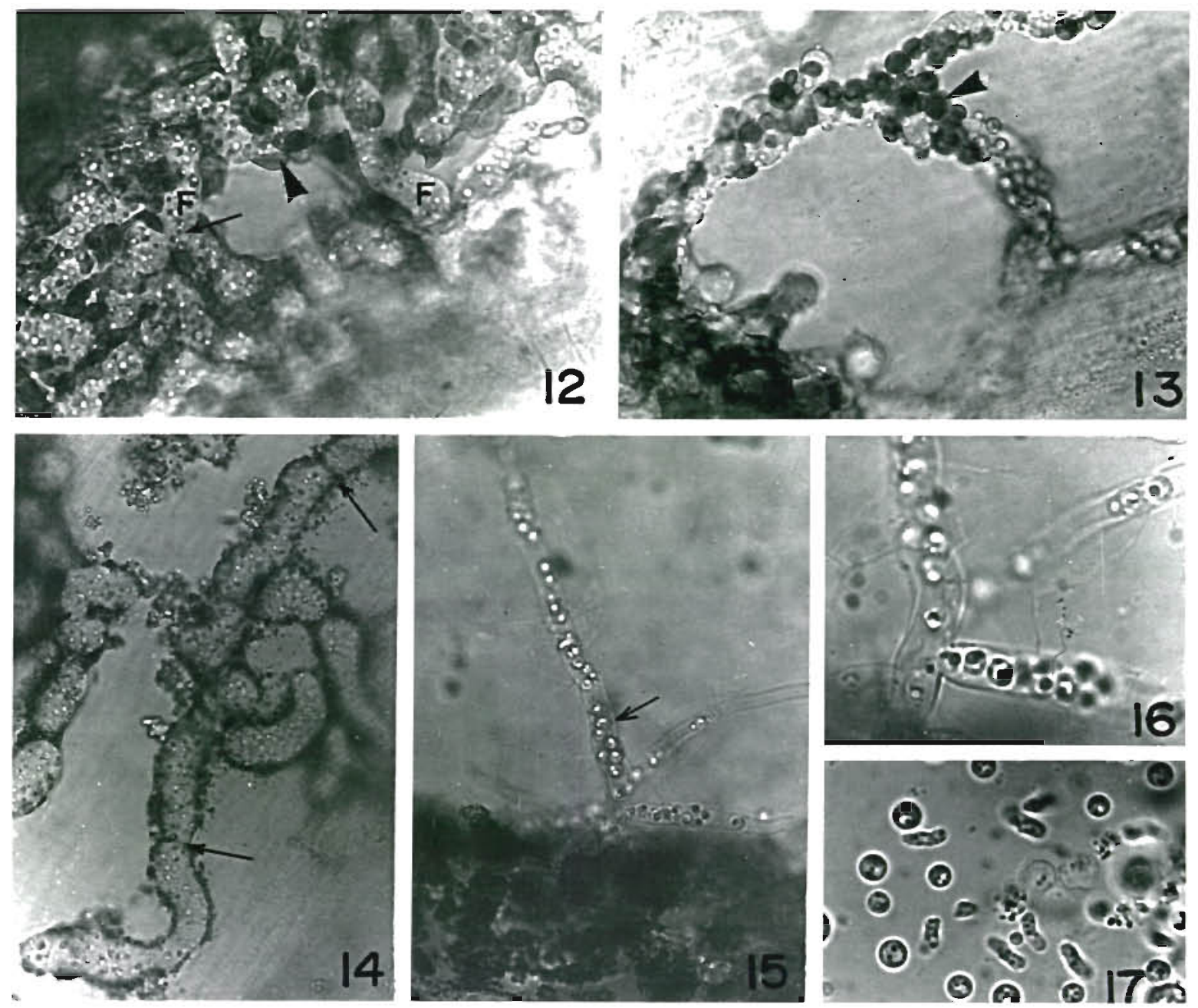

Fig. 12 to 17. Chaetomorpha media parasitised by Pontisma lagenidioides. Fully developed sporangia inside the host cell. Fig. 12. Lobed fungal sporangia (F) with glistening oil globules (arrow). Note the host chloroplast (dark in colour) deposited all along the sporangial wall (arrowhead) $(\times 900)$. Fig. 13. Segmented fungal thallus forming a ring. Note the dark rounded chloroplasts (arrowhead) deposited along the sporangia ( $\times 900$ ). Fig. 14. Oil globules (arrows show septa). Note the empty space in the host cell and degenerated host chloroplasts (as dark granulated deposits). Fig. 15. Mass of fungal sporangia lying among the degenerated brown chloroplasts of the host. Discharge tube of one of the sporangia is seen at the margin (arrow) ( $x 400)$. Note the zoospores inside the discharge tube. Fig. 16. A branched discharge tube with zoospores emerging ( $\times 900)$. Fig. 17. Encysted zoospores $(\times 900)$

\section{DISCUSSION}

The studies show the potential of these pathogens to cause diseases on marine algae. It has to be ascertained by further work to what degree these fungi are patho- gens on their hosts in nature. Fungal parasites of marine algae have been detected in fresh, natural samples of algae (C. Raghukumar 1986a, c, Molina 1986). Incubation of algae under laboratory conditions enhances any infection present (Sparrow 1960) and

Fig. 4 to 11 Developmental stages of the fungus Pontisma lagenidioides in the green alga Chaetomorpha media. F: fungal sporangia; $\mathrm{H}$ : host cell ( $\mathrm{C}$. media cell). Fig. 4. Knob-like stage of the fungus $(\mathrm{F})(\times 500)$, inside the host cell $(\mathrm{H})$. Fig. 5 . Multiple infection results in appearance of many knobs inside the host $(\times 700)$. Fig. 6. developing tubular thallus of the fungus $(F)(\times 1000)$. Fig. 7. Tubular, branched and segmenting (arrow) thallus of the fungus $(F)(\times 1000)$. Fig. 8 . Segmented fungal thallus filling the host cell. Note the healthy host cell nearby $(H)(\times 400)$. Fig. $9 \& 10$. Fragmented fungal thallus $(F)$; the host is devoid of naturally distributed chloroplasts $(\times 500)$. Fig. 11. Fungal sporangia $(F)$ with oil globules (arrow). Note the dark coloured brown pigment (arrowhead) deposited all along the sporangia $(\times 900)$ 

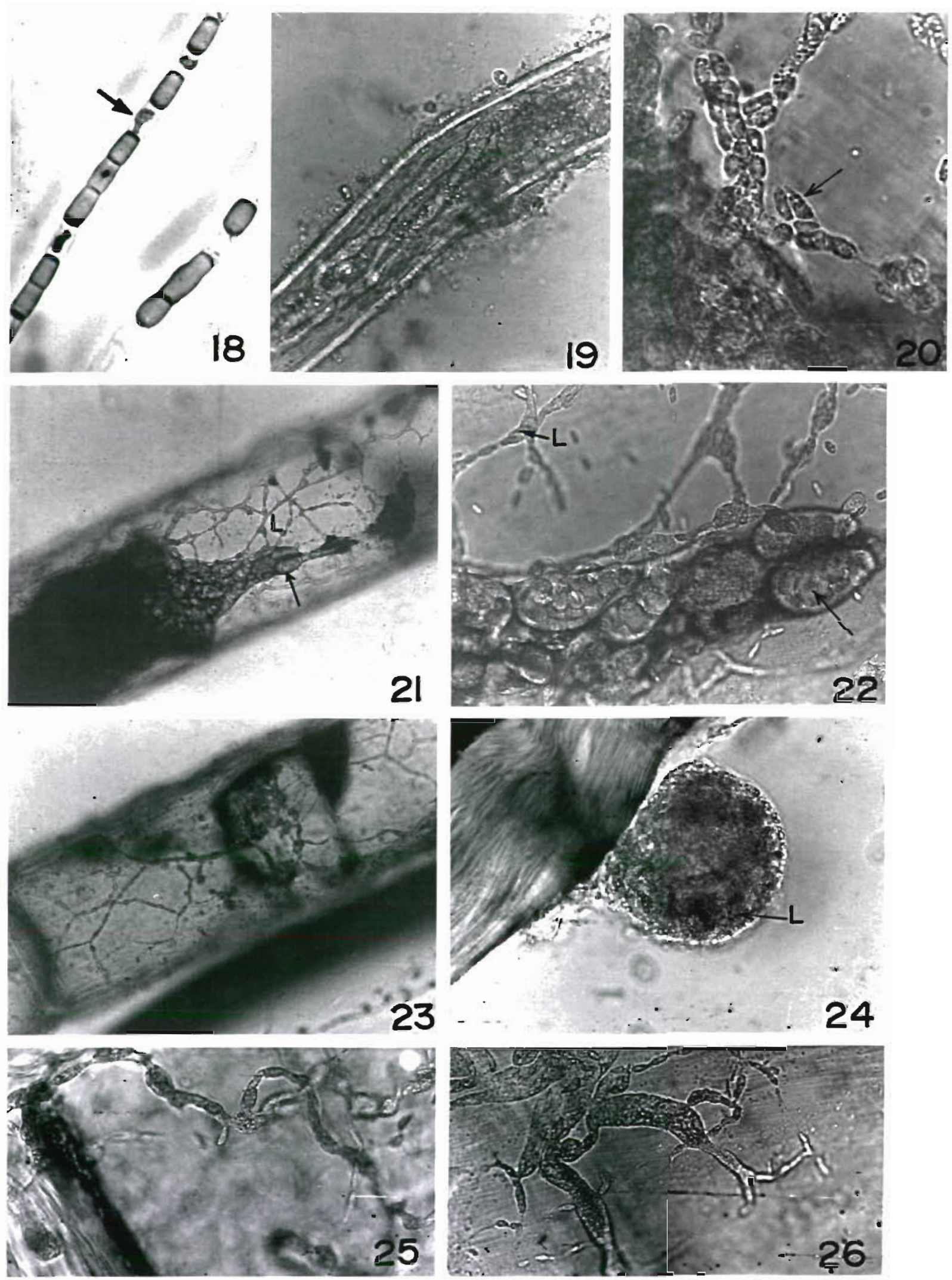
Table 1. List of parasitic fungi on marine algae collected from east coast of south India

\begin{tabular}{|c|c|c|c|}
\hline Host & Fungus & Locality & Relationship \\
\hline Chaetomorpha media & Pontisma lagendioides & Mandapam & Pathogenic \\
\hline Cladophora gracilis & Sirolpidium bryopsidis & Tuticorin & Pathogenic \\
\hline C. expansa & Olpidium rostriferum & Mandapam & Pathogenic \\
\hline C. fascicularis & Olpidium rostriferum & Mandapam & Pathogenic \\
\hline C. frascatii & Olpidium rostriferum & Mandapam & Pathogenic \\
\hline Centroceras clavulatum & Chytridium polysiphoniae & Mandapam & Parasitic \\
\hline Sphacelaria sp. & Chytridium polysiphoniae & Mandapam & Parasitic \\
\hline Caulerpa cupressoides & Thraustochytrid & Mandapam & Saprophytic \\
\hline Chaetomorpha media & Labyrinthula & Mandapam & Pathogenic \\
\hline Lyngbya sp. & Labyrinthula & Mandapam & Pathogenic \\
\hline Cladophora sp. & Labyrinthula & Mandapam & Pathogenic \\
\hline Rhizoclonium sp. & Labyrinthula and Olpidium sp. & Mandapam & Pathogenic \\
\hline Lobophora variegata & Labyrinthula & Mandapam & ? \\
\hline Laurencia sp. & Labyrinthula & Mandapam & ? \\
\hline
\end{tabular}

enables one to study the development of the fungal parasite and the disease symptoms in the host in detail (Schnepf et al. 1978, Molina 1986).

The fungal pathogen of Chaetomorpha media was identified as belonging to the genus Pontisma, described by Sparrow (1960), in possessing the fungal thallus which is broadly tubular, often with short irregular branches which do not disarticulate completely. The measurements of sporangia, zoospores and discharge tube correspond to those of $P$. lagenidioides (Sparrow 1960). However, the host on which it is reported here is new and it has not previously been reported as a pathogen. The fungus seems to be very host-specific as it was not observed to infect other green algae such as Cladophora sp., Ulva lactuca and Chaetomorpha linum.

Labyrinthula sp. has not been reported earlier as a virulent pathogen of Chaetomorpha media and Lyngbya sp. As seen from Fig. 36, it was also isolated from a brown and a red alga where it did not cause any visible symptoms. C. Raghukumar (1986c) has previously reported Labyrinthula as a serious pathogen of Rhizoclonium sp. and Cladophora sp. collected from the Lakshadweep islands in the Indian Ocean. Some of the above-mentioned algae are major sources of fouling on marine structures. Labyrinthula could make a good candidate as a biological control agent.

Labyrinthula sp. growing on the fungal sporangia Pontisma lagenidioides suggests its hyperparasitic nature, which needs to be further confirmed. Suggested hyperparasitism and a wide range of hosts make Labyrinthula a versatile organism. Labyrinthula spp. have been associated with the wasting disease of Zostera marina (Porter 1986), where they were able to penetrate the cell walls of the seagrasses (Perkins 1973).

An epiphytic chytrid was found growing abundantly on the red alga Centroceras clavulatum and on the brown alga Sphacelaria sp. (Table 1). It was identified to be Chytridium polysiphoniae which was earlier reported (C. Raghukumar 1986a) to be growing on C. clavulatum from Goa. Another phycomycetous fungus, Sirolpidium bryopsidis (de Bruyne) H.E. Petersen, caused terminal browning of the algal filaments in the green alga Cladophora gracilis. This fungus was also reported to cause similar symptoms in Cladophora frascatii collected from Goa and Lakshadweep islands (Raghukumar 1986c). Browning of cells of the green alga Cladophora expansa, Cladophora fascicularis and C. frascatii and Rhizoclonium sp. was observed to be caused by Olpidium rostriferum Tokunaga (Table 1). This fungus was also described in detail earlier (Raghukumar 1986c) from the Goa coast where it caused extensive damage to $C$. frascatii in nature. It was also reported to be occurring in the same host in the Lakshadweep islands.

Intertidal regions in and around Mandapam have luxuriant algal growth (pers. obs.). It would be

Fig. 18 to 26. Infection of Chaetomorpha media by Labyrinthula sp. L: Labyrinthula cells. Fig. 18. C. media filament infected by Labyrinthula (arrow) as seen under the stereomicroscope $(\times 3.3)$. Fig. 19. The basal portion of $C$. media filament filled with Labyrinthula cells $(\times 400)$. Fig. 20. Spindle shaped cells of Labyrinthula growing inside the host cell (arrow) ( $\times 900)$. Fig. 21. Labyrinthula (L) growing as hyperparasite on sporangia of $P$. lagenidioides (arrow) $(\times 400)$. Fig. 22. The same at higher magnification $(\times 900)$. Fig. 23. Labyrinthula cultured on autoclaved filaments of $C$. media $(\times 400)$. Fig. 24. Labyrinthula forming large sorus $(\mathrm{L})$ in the autoclaved filament of $C$. media $(\times 900)$. Fig. 25. Labyrinthula on autoclaved filaments of $C$. media $(\times 900)$. Fig. 26. Labyrinthula in culture forming large sori $(\times 900)$ 

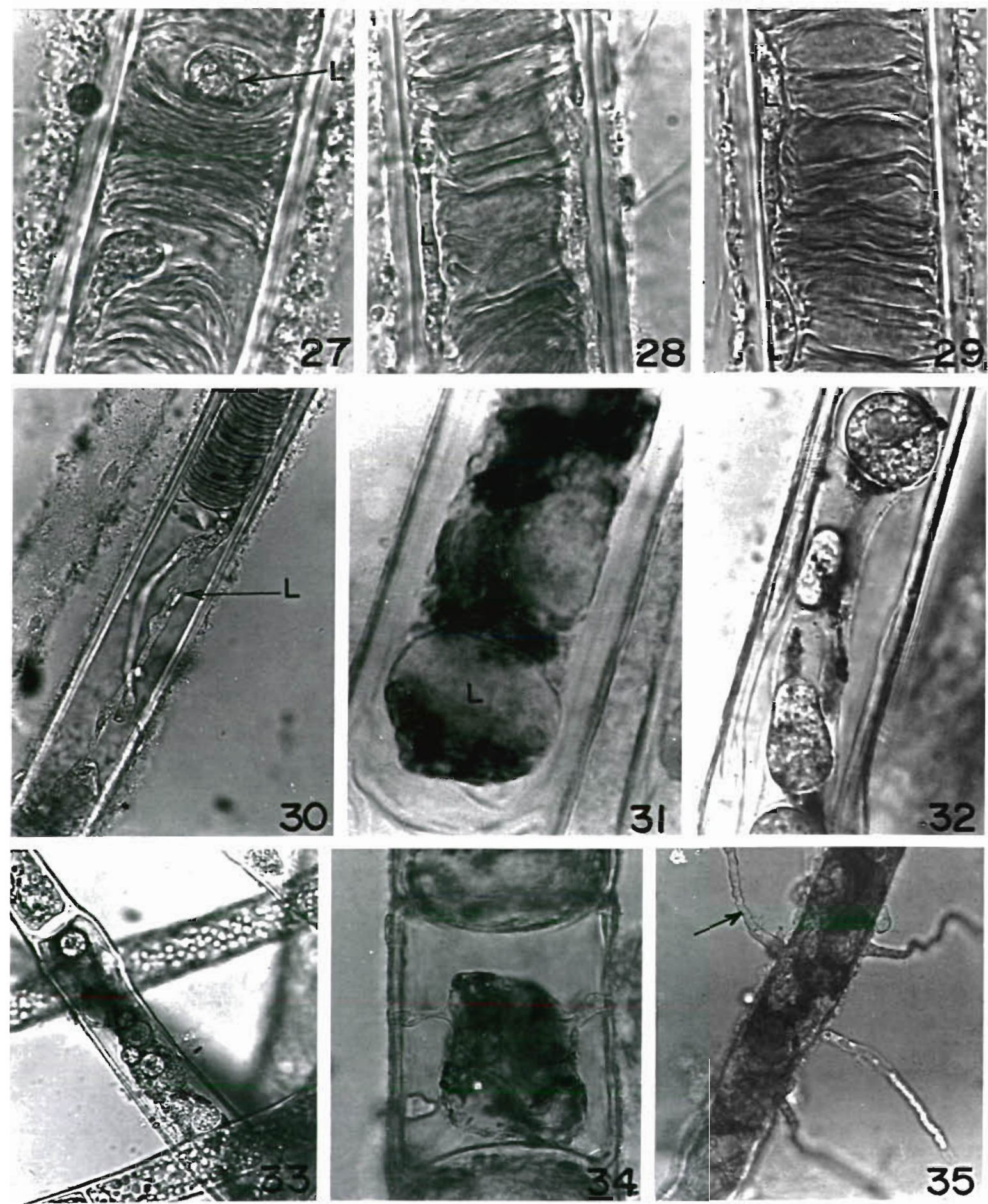

Fig. 27 to 35. Infection of marine algae by Labyrinthula sp., Olpidium sp. and Sirolpidium sp. Fig. 27 to 29. Labyrinthula infection (L) of the blue green alga Lyngbya sp. $(\times 900)$ Fig. 30. Spindle shaped cells of Labyrinthula (L) growing inside the host Lyngbya $\mathrm{sp}$. wherever the fungus is growing, the host is devoid of its content. Fig. 31. Sori formation of Labyrinthula in Chaetomorpha media. The dark-coloured areas are chloroplast masses and round light-coloured areas are sori (L) ( $\times 500)$. Fig. 32. Olpidium rostriferum sporangia in the marine green alga Cladophora frascatii $(\times 400)$. Fig. 33. The same $(\times 250)$. Fig. 34 . O. rostriferum infection in Rhizoclonium sp. ( $\times$ 500). Fig. 35. Sirolpidium bryopsidis infection in the marine green alga Cladophora sp. Sporangia with long discharge tubes (arrow) $(\times 250)$ 


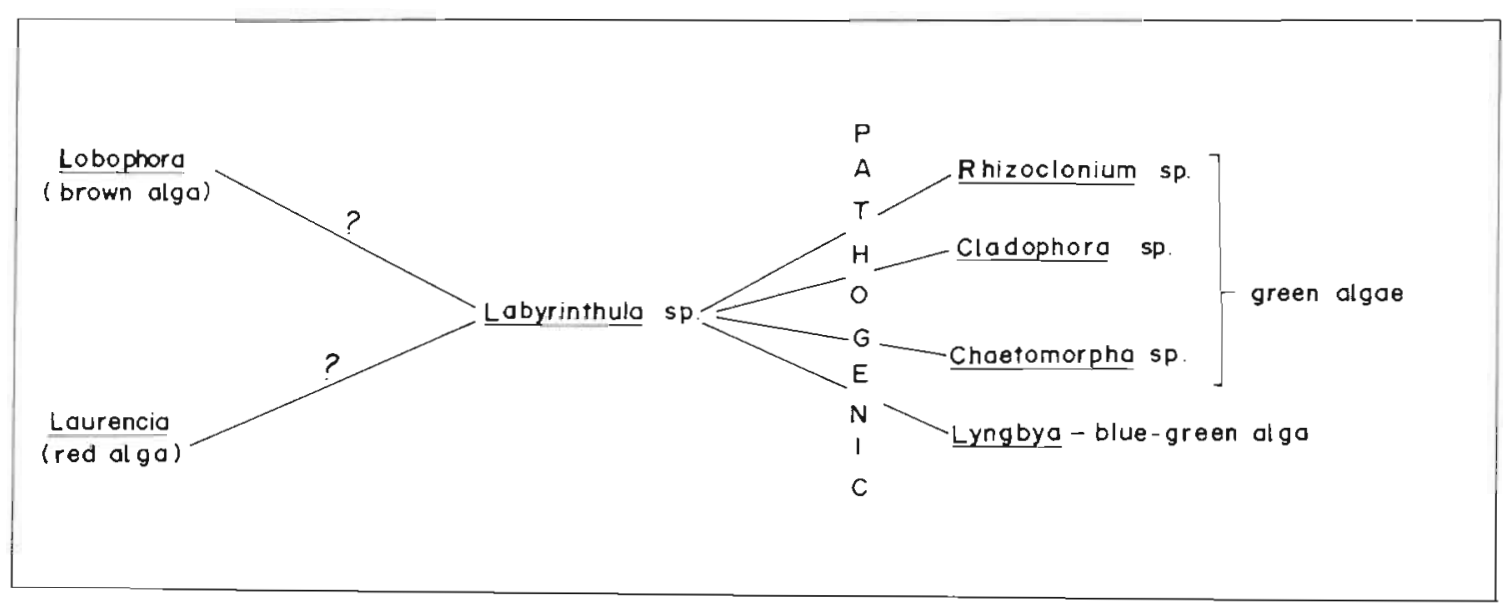

Fig. 36. Labyrinthula sp. Schematic diagram showing the host range

expected that in areas of high densities of algal cover, either natural or artificial, diseases would be present (Andrews 1976). Although the fungi isolated in this study were only observed to be pathogenic in the laboratory, they could still be potential pathogens when conditions become unfavourable for the host in nature.

Acknowledgements. I thank Dr S. Raghukumar for critically reading the manuscript. I acknowledge the help of $\mathrm{Mr} \mathrm{U}$. Sirsat and $\mathrm{Mr} \mathrm{A}$. Sheikh in printing negatives. My thanks are due to Miss Vijaya Ambiye for identifying some of the algae.

\section{LITERATURE CITED}

Andrews, J. H. (1976). The pathology of marine algae. Biol. Rev. 51: 211-253

Bott, T. L., Rogenmuser, K. (1980). Fungal pathogen of Cladophora glomerata (Chlorophyta). Appl. environ. Microbiol 40: 977-980

Molina, F. I. (1986). Petersenia pollagaster (Oomycetes): an invasive fungal pathogen of Chondrus crispus (Rhodophyceae). In: Moss, S. T. (ed.) The biology of marine fungi. Cambridge Univ. Press, Cambridge, p. 165-175

Perkins, F. O. (1973). Observations of thraustochytriaceous
(Phycomycetes) and labyrinthulid (Rhizopoda) - an electron microscope study. Can. J. Bot. 51. 485-491

Porter, D. (1986). Mycoses of marine organisms: an overview of pathogenic fungi. In: Moss, S. T (ed.) The biology of marine fungi. Cambridge Univ. Press, Cambridge, p. 141-153

Raghukumar, C. (1986a). Chytridium polysiphoniae - a fungal pathogen on the red alga, Centroceras clavulatum (C. Agardh) Montagne, from Goa. Indian J. mar. Sci. 15: $42-44$

Raghukumar, C. (1986b). Thraustochytrid fungi associated with marine algae. Indian J. mar. Sci. 15: 121-122

Raghukumar, C. (1986c). Fungal parasites of the marine green algae, Cladophora and Rhizoclonium. Botanica mar. 29: 289-297

Raghukumar, C. (1987). Fungal parasites of the green alga Chaetomorpha media. Dis. aquat Org. 3: 147-150

Raghukumar, S. (1986). Enumeration of thraustochytrids (heterotrophic microorganisms) from the Arabian Sea. Mahasagar Bull natn. Inst. Oceanogr 18: 457-465

Redhead, K., Wright, S. J. L. (1978). Isolation and properties of fungi that lyse blue-green algae. Appl. environ. Microbiol. 35: $962-969$

Schnepf, E., Deichgräber, G., Drebes, G. (1978). Development and ultrastructure of the marine, parasitic oomycete, Lagenisma coscinodisci Drebes (Lagenidiales). Thallus zoosporangium, mitosis and meiosis. Arch. Microbiol. 116 $141-150$

Sparrow, F. K., Jr (1960). Aquatic Phycomycetes. 2nd edn Univ. of Michigan Press, Ann Arbor 